\title{
A MODEL TO ESTIMATE THE PASSENGER RAIL LIBERALISATION: THE CASE OF SERBIA
}

\author{
Slavko Vesković ${ }^{1}$, Vera Raičević ${ }^{2}$, Gordan Stojić ${ }^{3}$, Sanjin Milinković ${ }^{4}$ \\ 1,2,4 University of Belgrade, Faculty of Transport and Traffic Engineering, Vojvode Stepe 305, 11000 Belgrade, \\ Serbia \\ ${ }^{3}$ University of Novi Sad, Faculty of Technical Sciences, Trg Dositeja Obradovica 6, 21000 Novi Sad, Serbia
}

Received 24 February 2012; accepted 19 July 2012

\begin{abstract}
Passenger rail transport market share has been drastically reduced in the last fifty years. The reforms were aimed at opening the market of railway services and development of competition in the railway sector in order to obtain the benefits of "market forces" and reduction of interventions in the railway sector. Determination of the level of reform often causes confusion and conflicting opinions. It involves the application of intuition and subjective assessments and is not used as a direct method of research, but as a summary of methods of reasoning on the current position. This suggests that it is appropriate to use the theory of fuzzy logic to evaluate the level of railway reform. Fuzzy model calculates the level of evaluation railway liberalization as a output variable where inputs are defined as: the dynamics of execution; number of reform steps taken; the implementation of transport policy; etc. The evaluation of the level of liberalization of the railway market and railway reforms is an important process which shows in which stage the countries are. Synchronization of reform level is very important for countries in the region to establish a stable transport market.
\end{abstract}

Keywords: railway, passenger transport, market liberalization, obligation of public transport, traffic extern costs, fuzzy model.

\section{Introduction}

Regardless of safety, energy savings, less environmental impact than other modes of transport and other advantages of passenger transport by rail, its share on transport market is dramatically reduced in the second half of the twentieth century (White Paper, 2001). The reasons lie in the presence of historical, traditional and national influences on the railway companies:

- high level of state intervention in the business of the national railways (counterproductive) - railway enterprises, under the influence of state control and intervention, are used as political and social goals instead of functioning on commercial principles;

- the costs are subsidized and there is no stimulus for change - high percentage of public transport, that is unprofitable is politically supported, while railway enterprises that are part of the public transport services are often left without adequate compensation.

${ }^{1}$ Corresponding author: veskos@sf.bg.ac.rs 
All national railways in Europe were the state organizations that carried out the economic and social policies, often burdened with obligations to provide public passenger transport services at lower prices than the actual costs and to finance the exploitation and development of the infrastructure.

This reduced their profitability and weakened market position. The national railway company has a monopoly, with no competition, innovation nor efficiency. It is also integrated, and represents operators and infrastructure managers. The regulatory framework is a national, i.e. national markets were protected, there is no competition from other national rail Operator, with there is no domestic market. Differences between the railway networks disrupted the development of rail transport at the regional level. At the same time, road traffic has grown due to the fact that in the field of rail transport market integration and optimization is not achieved (White Paper, 2001).

Due to the unprofitability of railway companies, there has been a process of accumulation of debt, in most European countries, particularly in the late 1980's (Stojić, 2010). Since the railroad companies continue to suffer from political interference, that economic efficiency was not a primary goal, but often focused on the completion of the current political structure, as a function of short-term, and long-term goals, a large, new debts that followed, were difficult to overcome. Loss of competitiveness of rail transport in modal split competition, growing trade deficit and the debt burden of states companies have launched a reform. Aim of the reforms was to ease the debt burden of its national railway company, and had a goal to:
- open the market of railway services,

- liberalize the railway sector,

- develop the competition in the railway sector in order to quality of service,

- reduce state intervention in the railway sector.

Market integration has demanded the removal of barriers that are existing in the internal transport market, arising from the fundamental technical differences between the various railway network (drag and special signals), as well as different approaches to ownership, control, management, finance and accountancy of railways and harmonization of the railway sector in terms of technical and legislative framework:

- Interoperability (technical standards),

- Security (common safety standards),

- Regulation (common legal framework, standard contracts).

The first task is the transformation of the state railway organization in conducting business operations in domestic European/international transport markets. The role of government is to create conditions for development of transportation system that meets the needs of society and support market mechanisms. In order to create a harmonized market environment in which the carriers of different modes of transport are affirmed on the basis of equal conditions, the competition must take into account all generated expenses. The total cost generated in the performance of services are consisted not only of the direct costs of transportation, the cost of infrastructure, security, control, exploitation and compensation of damages caused by accident, but also of compensational costs for damage caused to the environment (CER, 2005). 


\section{European Policy and Legal Framework}

In year 1985 (The second intergovernmental conference) Commission drew up the socalled White Paper on the future development of common transport policy, published in year 1995 which proclaimed the Four Freedoms of the EU - free movement of people, goods, capital and services. The basic principle was to open the transport market. Key role in the development of rail transport market is Directive 91/440/EEC on the development of the Union in order to strengthen entrepreneurship and competitiveness of rail transport. Maastricht Declaration of year 1992 confirms the crucial role of transport in economic development of the community and launches the idea of trans-European network, which then enabled a developing of a plan of transport infrastructure at European level. The measures to open transport market and to transform the national transport networks into a single European network are presented. Have strengthened political, institutional and financial foundations of transport policy and promoted the idea of trans-European network and later development of transport infrastructure plan, with financial assistance of the Union (White Paper, 1995).

It also provides for the reduction of gasoline use and the use of alternative fuels, simultaneously with the appearance of "Action Plan for Sustainable Development in the XXI century" (Milutinović, 2004) ${ }^{2}$ that encourages the adaptation of transport in compliance

\footnotetext{
2 "Agenda 21 is an action plan for sustainable development in the XXI century adopted at the highest level of the United Nations Conference on Environment and Development (UNCED) - the Earth Summit - held in Rio de Janeiro in June 1992. The term "sustainable development" was established in 1989, and was officially proclaimed in the Bergen Declaration of 1990 as development that meets the needs of the present, so that leaves the possibility of future generations to meet their own needs and to develop themselves."
}

with the policy of protection of environment introduced in the policy of the EU. EU Transport Council has defined its strategy that is based on the balanced development of different forms of transport.

For achieving sustainable transport systems (White Paper, 2001) some of the proposed measures to be taken are:

1.Establishing a system of charging for external costs and the cost of infrastructure for all transport modes;

2. Change in transport means distribution: from road to railways;

\section{Construction of trans-European transport} network, with priority to eliminate bottlenecks in the railway network (rehabilitation of railways as a top priority in the common transport policy);

\section{Integration of rail transport in the single market.}

The success of shift to all forms of transport will depend mostly on the possibilities to establish a single railway market and allow the competition arrival of new railway undertakings. Revitalization of the rail sector means to introduce competition and availability of railway infrastructure companies.

Liberalization process of railway transportation began with the opening of markets for international transport of goods, “open access" - for international operators and groups for combined transport of 1.1.1993. The next step was the open access for freight transport on an identified Trans-European network since 2003. Rail transport for national 
and international freight service goods is fully liberalized in the EU from 1.1.2007. Liberalization of railway transport passenger service was introduced from 1.1.2010 after the adoption of the Third Railway Package. This means that any licensed EU railway companies, with the necessary safety certificate may apply for infrastructure capacity - the route, in domestic and international freight traffic, and international rail passenger transport, across the EU rail network. The market for the national rail passenger transport services are still not open to cross-border competition.

Internal rail market is created through a gradual opening of national markets by establishing conditions that provide third parties access to its rail network on the basis of published and non-discriminatory conditions of access. The Commission has proposed to open up the market through the regulated competition to guarantee transparency, quality and participation of public transport (services of general economic interest that meet certain conditions, for example frequency and accuracy, sufficient capacity, privileges for certain categories of users). National or local government organized public transport (to meet certain requirements to provide criteria for the protection of health and safety of passengers, the availability of services, level of transparency and cost of transport and the limited duration of services) in the form of public service contracts to be concluded by tender for a period of 5 years.

The third railway package (adopted in December 2007) introduces the liberalization of international services, rules on passenger rights and certified engineers contains:

- Directive 2007/58/EC of 23.10.2007 amending Directive 91/440/EEC and
2001/14/EC (the first railway package): the objective is further opening the market of railway services (expansion of access rights) without going into the Public Service Obligation and the application field of the international passenger traffic within the EU (transit Union is off).

- Regulation (EC) 1371/2007 on the rights and obligations of rail passengers to replace the repealed Regulation 1191/69 and $1107 / 70$.

- Directive 2007/59/EC on the certification of train drivers in the railway system in the community, sets out the conditions and procedures for the certification of train drivers.

- Regulation (EC) 1370/2007, of 23.10.2007 on services of public passenger transport on railways and roads, with aim of defining the code of practice of the competent authority in the field of public transport, to guarantee the delivery of services of general interest.

The legal basis for the liberalization of railway traffic in the Republic of Serbia is defined in the Law on Railways (2005). Right to transport passengers on the railway infrastructure may be performed by a public company (carrier) and a private company registered for performing activities of public transport (Articles 20-27), and the carrier which establishes the obligation to perform transportation of passengers as well as activities of public interest (Articles 70-77). Further activities that more closely regulate this area by additional legal forms and regulations are missing. 


\section{Procedures and Benefits of Liberalization}

Passenger traffic is developed under the growing pressure of increasing mobility of society. The inadequacy of the transport system results with congestions, poor quality of transport services and the constant delays, and hence the recommendation of the European Council for the revitalization of rail for optimum use of infrastructure, modernization of services and the integration of rail transport in the European market.

Integrated transport strategy for transEuropean network is based on the principle of gradual opening of the transport market. This strategy resulted in a gradual harmonization of domestic legislation with EU railway laws in line with national programs, with the gradual restructuring of the national railway sector.

Opening the market for rail transport implies gradual establishment and implementation of legal and institutional framework for the separation of infrastructure management and provision of transport services, including separate accounts, as well as the reorganization of railroads in the market-oriented company in accordance with the relevant EU legislation. Managers should ensure fair and transparent conditions for access to rail infrastructure. Of particular importance is the strategic goal to set the railways at financially sound basis. The most important measures are:

- Establishment of the legal and institutional conditions for infrastructure managers and railway companies, which will provide conditions for a stable financial management and strive to constantly improve their financial situation;
- Establishment of a contractual relationship with the state, and the liability of passenger transport infrastructure and ensuring that adequate compensation is given according to the defined standards of performance that are monitored;

- Establishment of independent and competent national institutions responsible for issuing licenses to railway companies and issuing safety certificates;

- Implementation of the concept of Obligations of public transport in passenger traffic, with the compensation of costs to the railway companies in difference between the tariff approved and actual cost of transport (White Paper, 1995).

Public funds transferred to the railway company from activities related to the provision of passenger transport services in the form of obligations on public of transport, will be shown separately in the accounts and cannot be transferred to activities relating to the provision of other services (European Railway Policy, 2007). Public funds paid to railway companies and infrastructure managers cannot be transferred between these companies. Such financial support is associated with the demands on performance that are monitored and goals related to reducing costs to improve competitiveness of rail compared to other transport modes (UIC, 2008).

\section{Analysis of Models to Determine the Level of Liberalization}

Determine the level of reform often causes confusion and conflicting opinions. Estimates are given based on experience, intuition 
and subjective assessments of institutions representatives and experts. Institution can be: the Government, ministries, agencies, companies themselves, EU agencies, financial institutions (World Bank - WB, European Bank for Reconstruction and Development - EBRD, International Monetary Fund IMF...). In addition, there is often uncertainty about the input data required for certain decisions. This suggests that there is a range of estimates of parameters characterized by uncertainty, subjectivity and imprecision. There is a similar problem with the evaluation of the railway reform. The theory of fuzzy sets (fuzzy - indistinct sets) is a very convenient device for the treatment of subjectivity, ambiguity and uncertainty (Stojić et al., 2009).

WB experts defined the criteria for evaluating the reform of railway and made their grade (Table 1). In accordance to certain criteria, reforms of the railway system, in Eastern Europe and Central Asia, in 2005, on the basis of statistical analysis, are considered as:

- Low: Albania, Azerbaijan, Belarus, Macedonia, Moldova, Turkey, Turkmenistan, etc.;

- Medium: Armenia, Croatia, Czech Republic, Georgia, Latvia, Russia, Uzbekistan, Serbia, Montenegro and Bosnia \& Herzegovina;

- High: Estonia, Bulgaria, Hungary, Kazakhstan, Poland, Romania and Slovak Republic.

In year 2007 there was a study about assessing the level of liberalization in the EU 27 (IBM, 2007). The study applied benchmarking method for evaluation of legal and practical obstacles to access to the railway market. Ranking list of countries in terms of liberalization of rail transport market was performed using LIB Index (index of liberalization), which was obtained based on the existence of external operators (external railway undertakings - RU). It was determined on the basis of two sub-indexes in five levels. First LEX Index, weight 0.2 (20\%), analyzes the extent to which state law allows access to the market. Second index - ACCESS index, with weight 0.8 , is the number of obstacles that emerges in practice and the percentage of accessibility to domestic market (law in action). Specific index, the COM Index, compares the level of competition. Countries are grouped into three groups (Fig. 1 and Fig. 2):

1.advanced level of liberalization: United Kingdom, Germany, Sweden and the Netherlands;

2. liberalization in progress: Austria, Denmark, Switzerland, Spain;

3. delayed liberalization: Luxembourg, France, Greece and Ireland.

Parameters by which it is possible to evaluate compliance and inconsistency of restructuring and liberalization of the railway can be viewed from three levels (IBM, 2007):

- level of institutional and regulatory arrangement of states in the railway sector;

- level of dynamics and the achieved state of the process of restructuring of the state railway company;

- level of establishing of the rail market, the number of operators or carriers in passenger traffic, and their participation in the railway market. 
One of the most recent estimation of the level of liberalization and reform of the railway market was made in year 2009 by using SWOT analysis (SEETO, 2009) that was related to the estimation of the level of liberalization of the railway market (Fig. 3).
It can be determined that the biggest market liberalization was achieved in Great Britain, Sweden and Germany, then in Romania, Bulgaria, Slovenia, Switzerland, Hungary, and France. In Serbia level of liberalization is unsatisfactory.

\section{Table 1}

Defining and Leveling Criteria by the Method of Railway Reform

\begin{tabular}{|c|c|c|c|c|}
\hline No. & Criteria & "Low" reforms & "Medium" reforms & "High" reforms \\
\hline 1. & $\begin{array}{l}\text { New regulations } \\
\text { on Railway }\end{array}$ & No new reform laws & $\begin{array}{l}\text { The new law refers to a com- } \\
\text { mercial orientation to the } \\
\text { market liberalization }\end{array}$ & $\begin{array}{c}\text { New laws on a strictly } \\
\text { commercial basis (market } \\
\text { liberalization) }\end{array}$ \\
\hline 2. & $\begin{array}{l}\text { Organizational } \\
\text { form }\end{array}$ & $\begin{array}{c}\text { Traditionally state-owned } \\
\text { enterprises (single company) }\end{array}$ & $\begin{array}{c}\text { Public company or limited } \\
\text { company }\end{array}$ & Private companies \\
\hline 3. & $\begin{array}{l}\text { Management } \\
\text { Structure }\end{array}$ & Managed by the government & $\begin{array}{l}\text { Separation of main sectors } \\
\text { inside the enterprise }\end{array}$ & $\begin{array}{l}\text { Corporate separation of the } \\
\text { main functions of businesses } \\
\text { (independent businesses) }\end{array}$ \\
\hline 4. & $\begin{array}{l}\text { Market competi- } \\
\text { tion and } \\
\text { privatization }\end{array}$ & $\begin{array}{l}\text { There is no minimal } \\
\text { competition / privatization } \\
\text { only the input-output } \\
\text { elements of the market }\end{array}$ & $\begin{array}{l}\text { Partial privatization / compe- } \\
\text { tition in the rail market }\end{array}$ & $\begin{array}{l}\text { The right of access to } \\
\text { infrastructure and the third } \\
\text { group operator }\end{array}$ \\
\hline 5. & $\begin{array}{l}\text { The obligation of } \\
\text { public transport }\end{array}$ & $\begin{array}{l}\text { Coverage from the income } \\
\text { in freight traffic }\end{array}$ & $\begin{array}{l}\text { Lump sum to cover the } \\
\text { deficit in passenger traffic }\end{array}$ & $\begin{array}{l}\text { Contracted on the basis of } \\
\text { detailed financial data }\end{array}$ \\
\hline 6. & $\begin{array}{c}\text { Adaptation to } \\
\text { changes }\end{array}$ & $\begin{array}{c}\text { The weak level } \\
\text { of adaptability of workers }\end{array}$ & $\begin{array}{c}\text { Intermediate level of } \\
\text { adaptability of workers }\end{array}$ & $\begin{array}{c}\text { The high level of } \\
\text { adaptability of workers }\end{array}$ \\
\hline 7. & $\begin{array}{l}\text { Commercial busi- } \\
\text { ness processes }\end{array}$ & / & In the development phase & Well developed \\
\hline
\end{tabular}

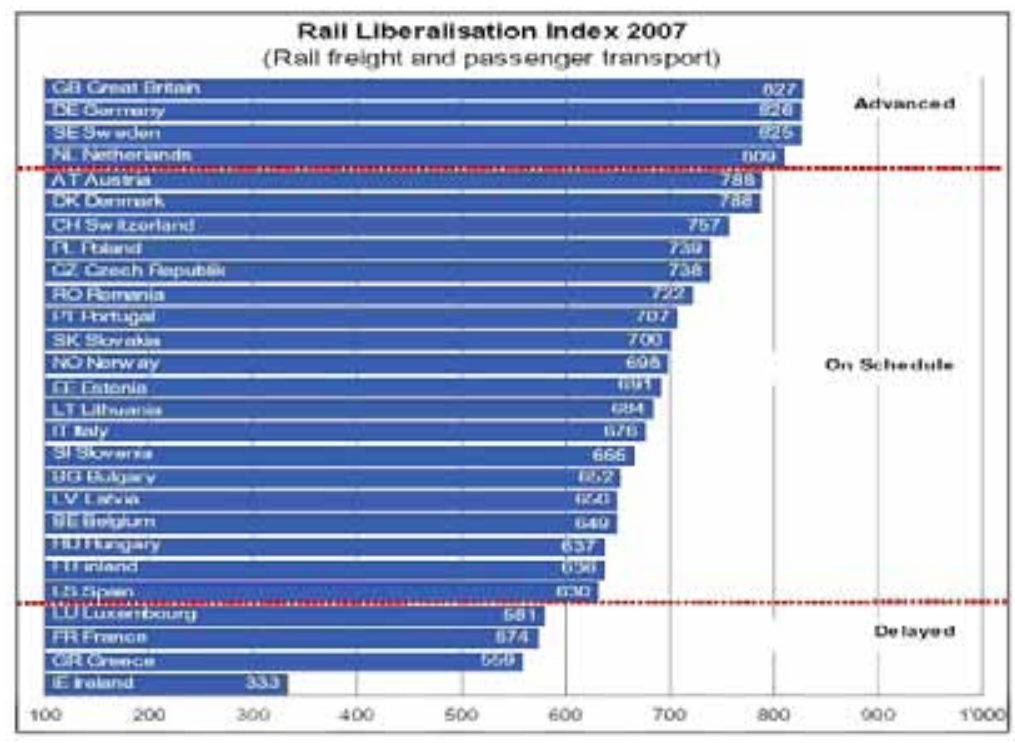

Fig. 1.

Scoreboard for the Liberalization of Railway Market

Source: IBM (2007) 


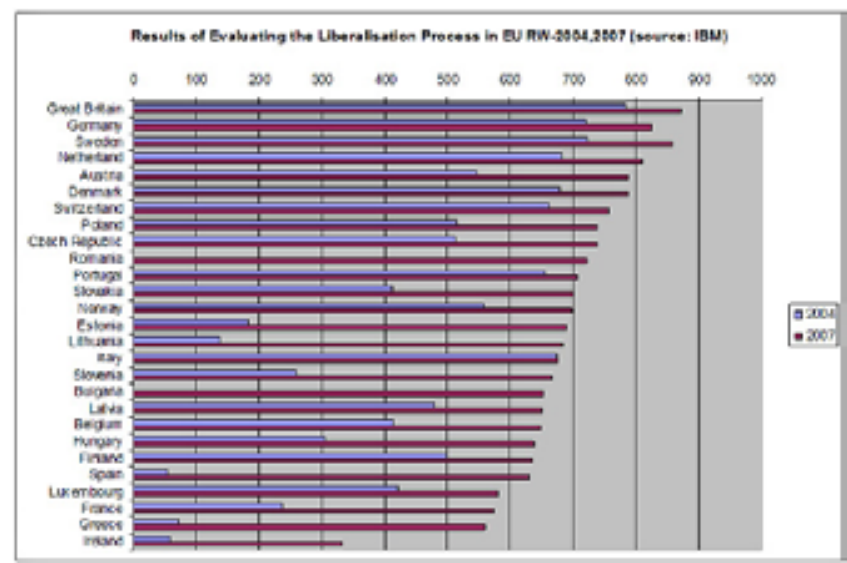

Fig. 2.

Comparative Analysis of State of Liberalization of Railway Market

For evaluating the level of implementation of the EU Directive basic criterion includes the division of the national railway company to independent companies. In the analysis, in addition to market liberalization and the implementation of EU directives, following criterion were taken into account: new laws on railways, open access to infrastructure, independence from the state in the management of railway companies, the existence of regulatory authority and the existence of Public Service Obligation (PSO).

To assess the impact of regulatory measures to liberalize markets and to establish market balance, a model of Computable General
Equilibrium (CGE) and benchmarking analysis can be found in the literature (Balistreri et al., 2009; Feraboli, 2006). Statistical analysis (CGE) does not take into account the uncertainty and the comparative method is based on the concept of benchmarking and innovative utilization of good practices and experiences. SWOT analysis is widely used. It involves the application of intuition and subjective assessments and is not used as a direct method of research, but as a summary of methods of reasoning on the current position (Dulanovic and Jasko, 2009). This suggests that it is appropriate to use the theory of fuzzy logic to evaluate the level of railway reform.

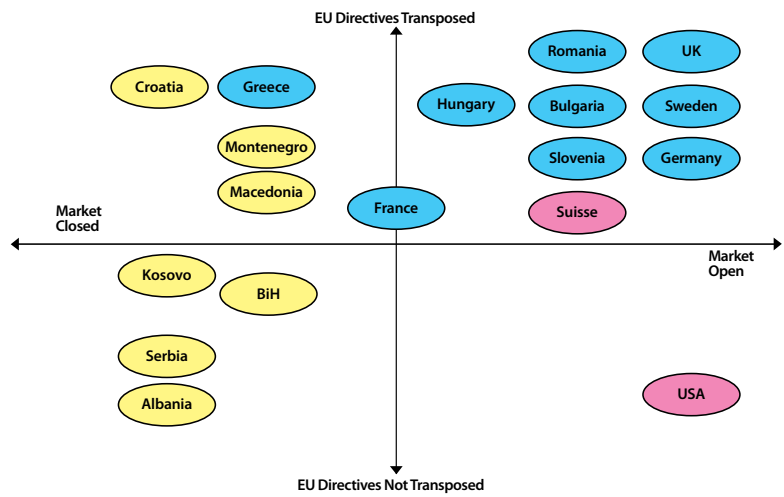

Fig. 3.

SWOT Analysis

Source: SEETO (2009) 
Fuzzy sets as a completely new concept were defined in the year 1965 (Zadeh, 1965) with the basic aim to introduce the mathematical formalized method of modelling uncertainty and performance in linguistics. Fuzzy logic has also found applications in information technology and expert systems, which are used to support decision-making.

The objective of this model is to enable the evaluation of the level of liberalization of rail passenger traffic in terms of the reforms in the national railway systems. It can be used in decision-making institutions for the purpose of approving funding reforms and the state railways, to determine the degree of harmonization with EU directives, for assessing the level of market liberalization, the degree of convergence with the EU, quality issued regulations, etc. With certain modifications to the rules and values of variables, it can be applied to other economic sectors such as the assessment of market liberalization or some of its elements: telecommunications, transport, agriculture, evaluation of reforms of judicial system, approaching the EU, compliance EU member states in various areas of reform and so on.

\section{Fuzzy Model to Determine the Level of Liberalization}

\subsection{Definition of Fuzzy Variables}

Let $\mathrm{A}$ be defined as a fuzzy output variable that is an estimate of the level of evaluation railway liberalization where there is uncertainty about the dynamics of execution, number of reform steps taken, the implementation of defined transport policy, social and political reasons preparedness of authorities for the implementation of reforms, policy changes, etc.

If the level of liberalization can be: "low", "medium" and "high" with valuation score 0-10 (e.g., for 5 points with the degree of membership of 0.5 we can argue that the level of liberalization is low, and with 1 that liberalization is medium (Fig. 4). A common scale from 0 to 10 is applied. Membership functions are (Eq. (1)):

$$
\begin{aligned}
& x \leq 0 \\
& 0 \leq x \leq 5 \\
& 5<x \leq 10 \\
& x>10
\end{aligned} \quad \mu_{\text {Ahigh }}(x)=\left\{\begin{array}{cl}
0 & x \leq 0 \\
\frac{x}{10} & 0 \leq x \leq 10 \\
1 & x \geq 10
\end{array}\right.
$$

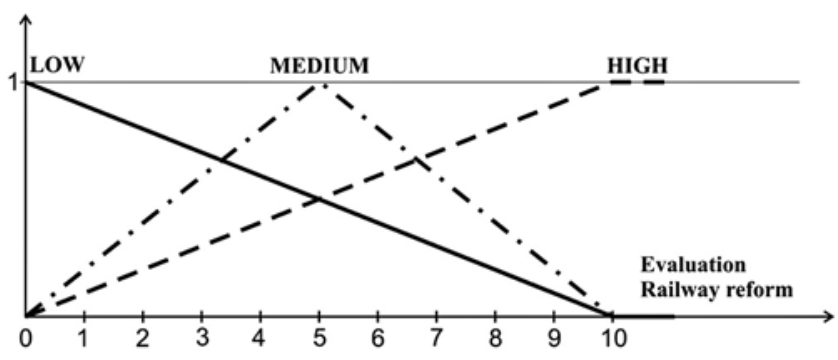

Fig. 4.

Fuzzy Membership Functions of Variable A 


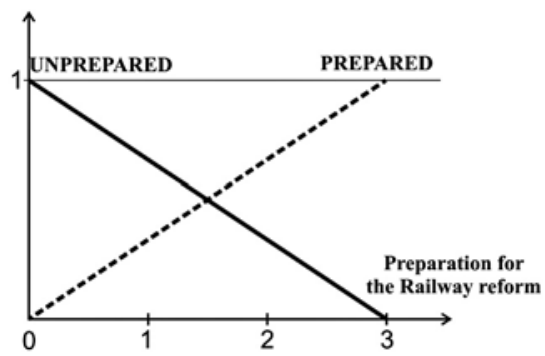

Fig. 5.

Fuzzy Membership Functions of Variable B

Restructuring of public railway companies is a process developed in the three phases: 1 . enforcing the law on railway (the EU Basic Regulative - Directive 91/440/EEC); 2. changing the public railway company into holding; 3. separating the infrastructural and transportation businesses into completely separate companies. Apart from the basic regulative, there is also an additional EU railway regulative in terms of the first, second and third directive sets.

As indicators for assessing the reforms the following input variables will be taken into account:

- Preparedness of the countries for liberalization of railways;

- Fulfillment of criteria for railway reform;

- Number of railway operators.

$$
\mu_{\text {Bunpr }}(x)=\left\{\begin{array}{cl}
1 & x \leq 0 \\
\frac{3-x}{3} & 0 \leq x \leq 3 \\
0 & x \geq 3
\end{array}\right.
$$

The number and type of criteria is an important element by which the level of reform of railway systems can be estimated. Let's define the
Practice and review of the experience of European countries shows that there are two approaches in the process of restructuring: gradual and radical. Gradual approach means a longer transition period, and a radical means "fast" and "sharp" transformation of the railway company in terms of its organization and relationship with the state authorities.

Let fuzzy variable B shows the phase state of readiness for the liberalization of the railway market. Suppose that there are "Unprepared" and "Prepared" state for liberalization (Fig. 5) (for example "Unprepared" indicates that phase of railway public companies restructuring is conducted with the degree of affiliation 1 , or a readiness of affiliation with a degree of $1 / 3, \ldots$, or if all three phases are conducted with the degree of 1 the railway market is "Prepared"). The membership functions (Eq. (2)) are defined:

$$
\mu_{\text {Bprep }}(x)= \begin{cases}1 & x \leq 0 \\ \frac{x}{3} & 0 \leq x \leq 3 \\ 0 & x>3\end{cases}
$$

following criteria for evaluating the reform of the railway system: 
$\mathrm{K}_{1}$ - "New regulations". If the first set is enforced than $K_{1}$ criterion is fulfilled. The basic regulative enforcement in the field of railway is included in the fuzzy variable "Prepared" (for the railway reforms).

$\mathrm{K}_{2}$ - "Improved management structure". The criterion $\mathrm{K}_{2}$ is considered fulfilled when the operators are converted into stock associations or they are private companies.

$\mathrm{K}_{3}$ - "Open access to infrastructure". The criterion $\mathrm{K}_{3}$ is considered fulfilled if there is a greater number of transporters in the railway system.

$\mathrm{K}_{4}$ - "Market liberalization" (Open access to operators). The criterion $\mathrm{K}_{4}$ is considered fulfilled if there is at least one international operator in the railway market.

$\mathrm{K}_{5}$ - "Market economy" (Commercial business of the companies on the market). The criterion $\mathrm{K}_{5}$ is considered fulfilled when, except for the established regulation, the state provides financial means for infrastructure controllers only for development of railway infrastructure.

$\mathrm{K}_{6}$ - "Subventions in the public transport (PSO)". The criterion $\mathrm{K}_{6}$ is considered fulfilled when the authorized organs provide financial means for agreed duties that are related to the transport of general interest.

$$
\begin{aligned}
& \mu_{\text {Cunic }}(x)=\left\{\begin{array}{cl}
1 & x \leq 1 \\
2-x & 1 \leq x \leq 2 \\
0 & x \geq 2
\end{array} \quad \mu_{\text {Comit }}(x)=\left\{\begin{array}{cl}
0 & x \leq 0 \\
\frac{x}{2} & 0 \leq x \leq 2 \\
1 & 2 \leq x \leq 3 \\
\frac{5-x}{2} & 3<x \leq 5 \\
0 & x \geq 5
\end{array}\right.\right. \\
& \mu_{\text {Csaic }}(x)=\left\{\begin{array}{cl}
0 & x \leq 2 \\
\frac{x-2}{2} & 2 \leq x \leq 4 \\
1 & 4 \leq x \leq 5 \\
\frac{7-x}{2} & 5<x \leq 7 \\
0 & x \geq 7
\end{array} \quad \mu_{\text {Cgric }}(x)=\left\{\begin{array}{cl}
0 & x \leq 5 \\
5-x \mid & 5 \leq x \leq 6 \\
1 & x \geq 6
\end{array}\right.\right.
\end{aligned}
$$

Fuzzy logic is defined using algorithms for approximate reasoning. The special significance of fuzzy logic is in the possibility of its application for modeling complex systems in which is very difficult to determine the correlation of certain variables that exist in the model. Possible and logical rules are with weight 1 , less possible 0.5 , illogical and practically impossible rules are with weight 0 .
$\mathrm{K}_{7}$ - "Reduce of redundancies" (Adjustment of the employees' number and structure). The criterion $\mathrm{K}_{7}$ is considered fulfilled when the rationalization of employees was made.

In literature, defining a criterion, as well as the evaluation of levels of reforms, is based on experience, intuition and subjective evaluation (Balistreri, 2009; Feraboli, 2006). Suppose that the estimation of the level of reform is "unsatisfactory-unic" (a readiness of affiliation with the degree of 1 if all three phases are conducted), "small-smic" (meeting the criteria 2 and 3 with the membership degree of 1 ), gric" (meeting the criteria 6 and 7 with the membership degree of 1) implementation of criteria (Fig. 6) and expressions (Eq. (3) and Eq. (4)). 


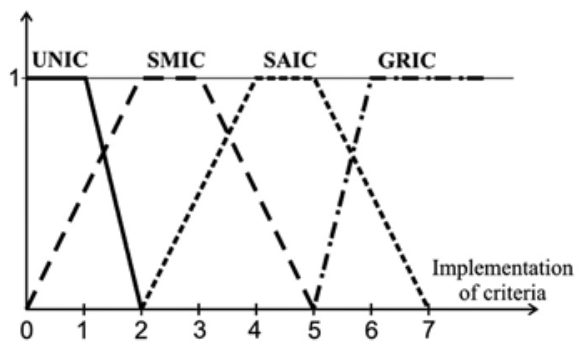

Fig. 6.

Fuzzy Membership Functions of Variable C

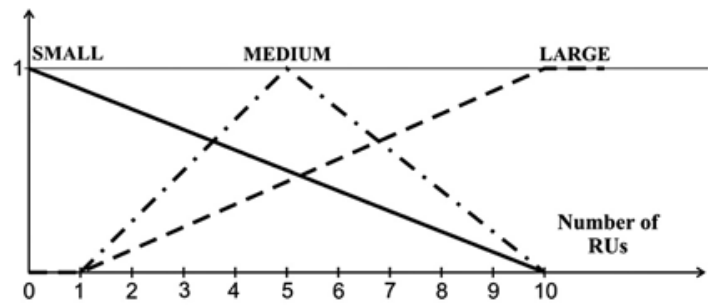

Fig. 7.

Fuzzy Membership Functions of Variable D

Suppose that the market may be "small" (only one operator into the market with the membership degree of 1 ), "medium" (around 5 operator market affiliation with level 1) and "large" (10 or more operators market

$\mu_{\text {Dsmall }}(x)=\left\{\begin{array}{cl}1 & x \leq 0 \\ \frac{10-x}{10} & 0 \leq x \leq 10 \\ 0 & x \geq 10\end{array} \quad \mu_{\text {Dlarge }}(x)=\left\{\begin{array}{ll}0 & x \leq 1 \\ \frac{x-1}{10} & 0<x<10 \\ 1 & x \geq 10\end{array} \quad \mu_{\text {Dnmal }}(x)= \begin{cases}0 & x \leq 1 \\ \frac{x-1}{5} & 1 \leq x<5 \\ \frac{10-x}{5} & 5 \leq x \leq 10 \\ 0 & x \geq 10\end{cases}\right.\right.$

Fuzzy logic is the base of fuzzy system. It enables making decisions based on incomplete information, and models based on fuzzy logic consist of the so-called "IF-THEN" rules. "IF-THEN" rules are interconnected with "ELSE” or "AND”.

$R^{r}$ :IF $x_{l}$ is $A_{l}^{r} A N D x_{2}$ is $A_{2}^{r} A N D \ldots A N D x_{n}$ is $A_{n}^{r}$ THEN $y_{l}$ is $B_{l}^{r}, y_{2}$ is $B_{2}^{r}, \ldots, y_{m}$ is $B_{m}^{r}$

where: $x \in X=X_{l} \times X_{2} \times \cdots \times X_{n}, y \in Y=Y_{l} \times Y_{2} \times \cdots \times Y_{m}$ and $A^{r}=A_{l}^{r} \times A_{2}^{r} \times \cdots \times A_{n}^{r} \subseteq X, B^{r}=B_{l}^{r} \times B_{2}^{r} \times \cdots \times B_{n}^{r} \subseteq Y$ are the fuzzy sets. affiliation with level 1) number of Railway Undertakings-Rus. Let $\mathrm{D}$ is a fuzzy variable that estimates the number of operators in the railway system (Fig. 7) with expressions (Eq. (5).

When we assume that $x=\left[x_{1}, x_{2}, \ldots, x_{n}\right]$ is a vector of features describing any object or state and $\mathrm{y}=\left[\mathrm{y}_{1}, \mathrm{y}_{2}, \ldots, \mathrm{y}_{\mathrm{m}}\right]$ is the vector of output values of a system, the rules are represented in the form (Eq. (6)): 
Algorithm for approximate reasoning to determine the level of reforms railway consists of 24 rules (the weighting factor determines the strength of logic for each rule):

1. If (Preparation is UNPREPARED) and (Criteria is UNIC or SMIC) and (Railway Undertakings is SMALL) then (Railway Reform is LOW) - weight: (1)

2. If (Preparation is UNPREPARED) and (Criteria is UNIC or SMIC) and (Railway Undertakings is MEDIUM) then (Railway Reform is LOW) - weight: (0.5)

3. If (Preparation is PREPARED) and (Criteria is UNIC or SMIC) and (Railway Undertakings is SMALL) then (Railway Reform is LOW) - weight: (1)

4. If (Preparation is PREPARED) and (Criteria is UNIC or SMIC) and (Railway Undertakings is MEDIUM) then (Railway Reform is LOW) - weight: (0.5)

5. If (Preparation is PREPARED) and (Criteria is ANY) and (Railway Undertakings is ANY) then (Railway Reform is MEDIUM) - weight: (1)

6. If (Preparation is PREPARED) and (Criteria is GRIC) and (Railway Undertakings is ANY) then (Railway Reform is HIGH) ${ }^{3}$ - weight: (1)

\subsection{Test Results}

The incoming variables in fuzzy systems are representing the so called linguistic variables.

\footnotetext{
${ }^{3}$ When the states are ready for railway reforms and there is a great fulfillment of criteria, but there is not a great number of operators on the market, it cannot be claimed that the reforms are high because there can be unattractiveness of the market itself.
}

The outcome is given in a continual phase. An adequate level of belonging is determined for all possible outcome sums of variables. After consideration of the level of affiliation of particular variables outcome value, defuzzification is made.

Defuzzification is the process of producing a quantifiable result in fuzzy logic, given fuzzy sets and corresponding membership degrees. It is typically needed in fuzzy control systems. These will have a number of rules that transform a number of variables into a fuzzy result, that is, the result is described in terms of membership in fuzzy sets. For example, rules designed to decide how much pressure to apply might result in "Decrease Pressure (15\%), Maintain Pressure (34\%), Increase Pressure (72\%)". Defuzzification is interpreting the membership degrees of the fuzzy sets into a specific decision or real value.

The simplest but least useful defuzzification method is to choose the set with the highest membership, in this case, "Increase Pressure" since it has a $72 \%$ membership, and ignore the others, and convert this $72 \%$ to some number. The problem with this approach is that it loses information. The rules that called for decreasing or maintaining pressure might as well have not been there in this case.

A common and useful defuzzification technique is center of gravity. First, the results of the rules must be added together in some way. The most typical fuzzy set membership function has the graph of a triangle. Then, if this triangle were to be cut in a straight horizontal line somewhere between the top and the bottom, and the top portion were to be removed, the remaining portion forms a trapezoid. The first step of defuzzification typically "chops off" parts of the graphs to 
form trapezoids (or other shapes if the initial shapes were not triangles). For example, if the output has "Decrease Pressure (15\%)", then this triangle will be cut $15 \%$ the way up from the bottom. In the most common technique, all of these trapezoids are then superimposed one upon another, forming a single geometric shape. Then, the centroid of this shape, called the fuzzy centroid, is calculated. The $\mathrm{x}$ coordinate of the centroid is the defuzzified value.

Defuzzification, which includes choice of one value of output variables, was done with the "middle of the maximum" method. Results of model are the levels of liberalization of the railway market for the randomly selected country (Fig. 8 and Fig. 9). Based on the results it can be concluded that Serbia is among countries with "low" level of liberalization of the railway market. Similar results were obtained with the model with Centroid defuzzification. This way railway reforms are graded based on a random choice of samples of countries (Fig. 9).

Fig. 8.

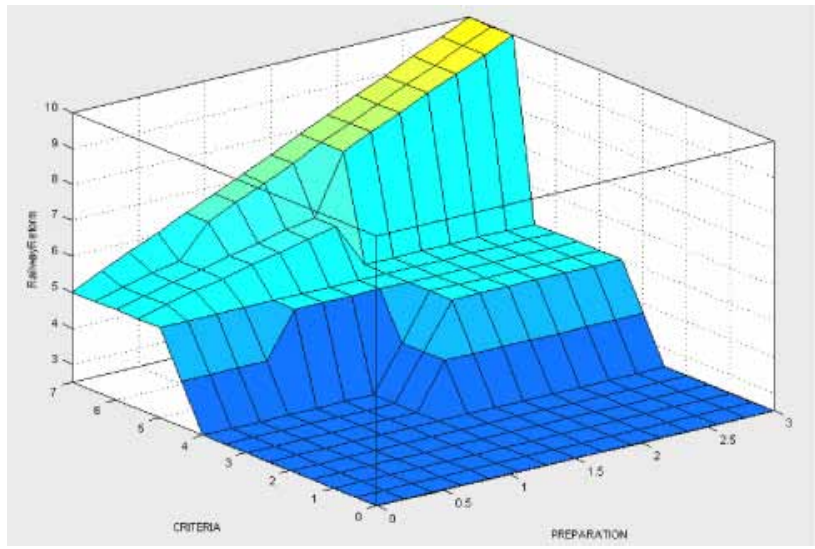

Variable $A$ in the Function of Variables B, C and D - Example of Serbian Reform

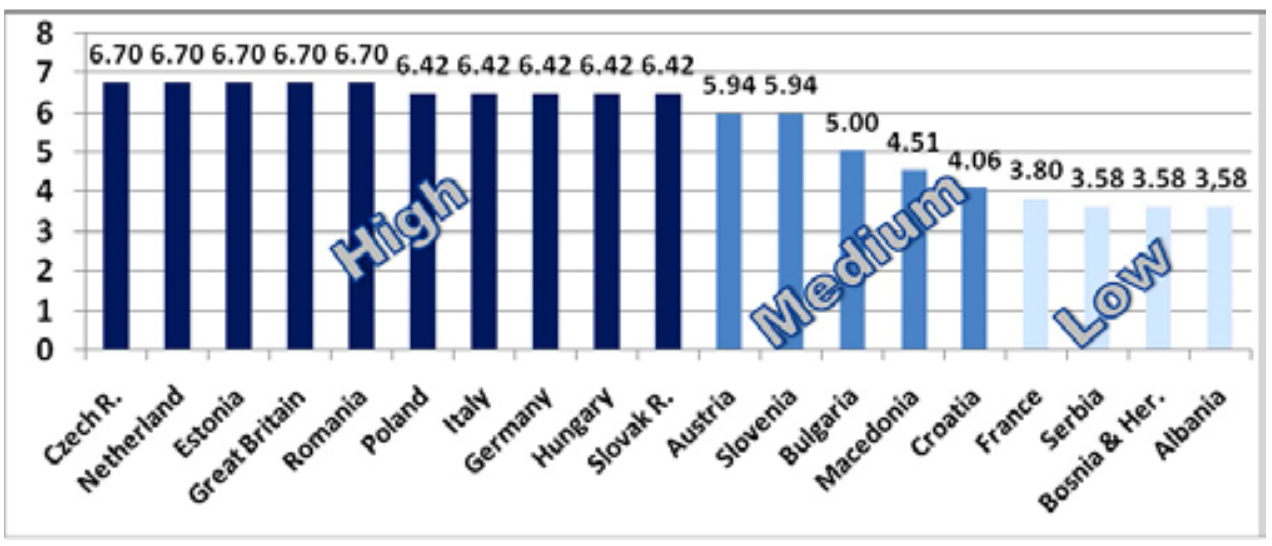

Fig. 9.

Railway Reforms Grade of Chosen Countries 
In order to assess the validity of the proposed model sensitivity analysis was performed by changing forms of membership functions of fuzzy sets for input and output variables and changing the methods of the operator analysis in these cases:

1. Membership functions have the triangular and trapezoidal form of fuzzy sets (Fig. 4 - Fig. 7), and the method used is "prod" (Product of array elements) for the operator
"AND", and method "probor" (Probably "OR") for the operator "OR" (Fig. 10);

2. Membership function takes the form of Gauss's curve (Fig. 11).

For the test cases of the defined fuzzy model (a. and b.) obtained evaluations are the same or with negligible differences. This indicates that the proposed fuzzy model for the evaluation of implemented railway reforms gives valid results.

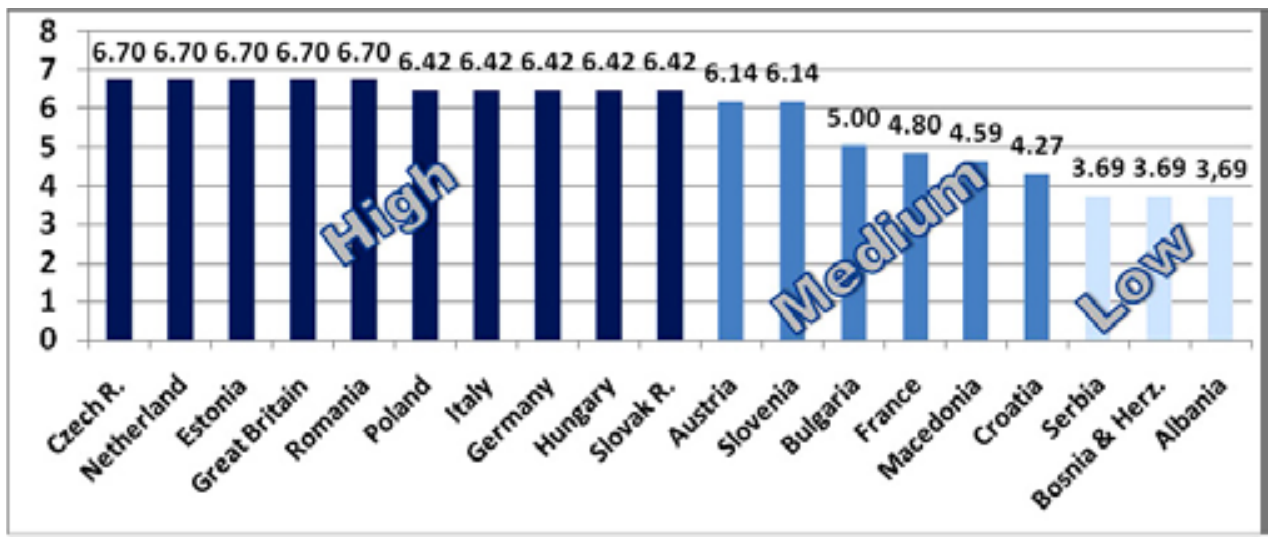

Fig. 10.

Railway Reforms Grade "Case a"

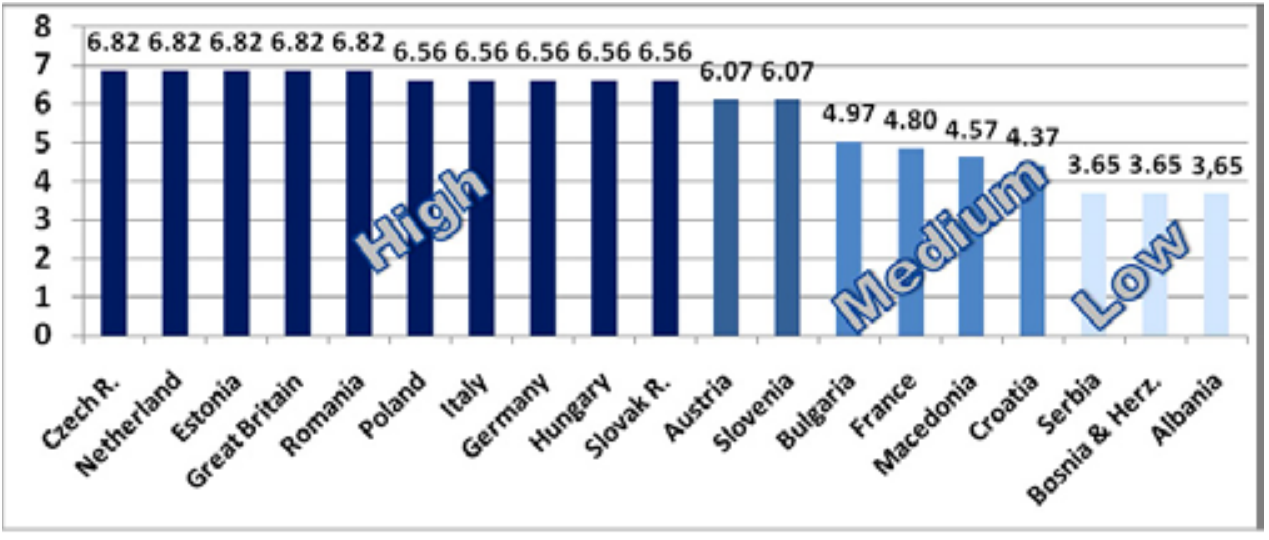

Fig. 11.

Railway Reforms Grade "Case b" 


\subsection{Validation of the Model}

Validation of the model is the process of determining the degree of agreement of data in real-system with data models. There is no an adopted unified assessment methodology of railway reforms which the results of fuzzy model presented in this paper could be compared with. Therefore, validation of the fuzzy model was made based on comparisons of the results of this model with the results of the evaluation of other models presented in this paper.

Table 2

Comparative Review of Observed Grades of Railway Reform Countries

\begin{tabular}{|c|c|c|}
\hline Model & Railway reform grade & Countries \\
\hline \multirow{3}{*}{ Fuzzy model } & $\begin{array}{l}\text { High reform (Advanced } \\
\text { or Market open and EU } \\
\text { directive transposed) }\end{array}$ & $\begin{array}{l}\text { Czech Republic, Netherlands, Estonia, Romania, Great Britain, } \\
\text { Poland, Italy, Germany, Hungary, Slovak Republic }\end{array}$ \\
\hline & $\begin{array}{c}\text { Medium reform (On } \\
\text { Schedule or Market } \\
\text { closed and EU directive } \\
\text { transposed) }\end{array}$ & Austria, Slovenia, Bulgaria, Macedonia, Croatia \\
\hline & $\begin{array}{l}\text { Low reform (Delayed or } \\
\text { Market closed and EU } \\
\text { directive not transposed) }\end{array}$ & France, Serbia, Bosnia \& Herzegovina, Albania \\
\hline \multirow{3}{*}{ WB experts } & High reform & Estonia, Bulgaria, Hungary, Poland, Romania, Slovak Republic \\
\hline & Medium reform & Armenia, Croatia, Czech Republic, Serbia, Bosnia \& Herzegovina \\
\hline & Low reform & Albania, Macedonia, \\
\hline \multirow{3}{*}{$\begin{array}{l}\text { Rail } \\
\text { liberalization } \\
\text { index }\end{array}$} & High reform & Great Britain, Germany, Netherlands, \\
\hline & Medium reform & $\begin{array}{c}\text { Austria, Slovenia, Bulgaria, Czech Republic, Slovak Republic, } \\
\text { Estonia, Poland }\end{array}$ \\
\hline & Low reform & $\begin{array}{l}\text { France } \\
\end{array}$ \\
\hline \multirow{3}{*}{$\begin{array}{l}\text { SWOT } \\
\text { analysis }\end{array}$} & High reform & Great Britain, Germany, Hungary, Romania, Bulgaria, Slovenia \\
\hline & Medium reform & Croatia, Macedonia, France \\
\hline & Low reform & Serbia, Bosnia \& Herzegovina, Albania \\
\hline
\end{tabular}

The sample of countries in which the evaluation of railway reform was done in observed cases is partially different (Table $2)$. However the results were consistent. Minor differences exist between the Rail liberalization index and the other models when it comes to countries that have just joined the EU, or were candidates for membership. Another reason for the slight difference is the time when the evaluation was done. Rail liberalization index evaluation is carried out in 2004-2007 and the WB in 2005. Evaluations by SEETO are from 2009, and presented fuzzy model from 2011. Certainly, some countries have made reforms in railway in the period between 2004 and 2011. Based on the abovementioned, it can be concluded that the presented fuzzy model gave satisfactory results. 


\section{Conclusion}

Evaluation of the level of liberalization of the railway market and railway reforms is an important process which shows in which stage the countries are. Synchronization of reform level is very important for countries in the region, because it can help to establish a stable transport market. This is especially important for the railways which are on the pan-European transit routes and corridors. The European rail system must not be "fragmented" on unsynchronized national railways because it does not contribute to creating a single European transport market, and thus the desired liberalization. It may also lead to reduced quality of railway services and the competitiveness of railways in the market.

Synchronization of railway reform was encouraged through various institutions and estimates of the level of reforms and liberalization are often required in the opinion of experts or by using inappropriate methods. The relevant parameters used in the methods include a large extent the uncertainty, subjectivity, ambiguity and vagueness.

This paper presents a new way of evaluating the liberalization of the railway market (passenger transport aspect) based on the theory of fuzzy sets. Model shown in this paper can be applied to other economic sectors, such as e.g. assessment of liberalization of markets in general or its individual elements, the level of implementation of various reform areas, etc.

\section{Acknowledgement}

This paper is supported by Ministry of Science and Technological Development of the Republic of Serbia (Project No. 36012).

\section{References}

Balistreri, E.J.; Rutherford, T.F.; Tarr, D.G. 2009. Modelling services liberalization: The case of Kenya, Economic Modelling, DOI: http://dx.doi.org/10.1016/j. econmod.2009.01.010, 26(3): 668-679.

Commission of the European Communities (1995): White paper-Preparation of the Associated Countries of Central and Eastern Europe for Integration into the Internal Market of the Union, Brussels, COM(95), 163 final. 41 p.

European Commission. 2007. Directive 2007/58/EC of the European Parliament and of the Council Directive of 23 October 2007 amending Council Directive 91/440/ EEC on the development of the Community's railways and Directive 2001/14/EC on the allocation of railway infrastructure capacity and the levying of charges for the use of railway infrastructure. Official Journal of the European Union, L 315: 44-50.

European Commission. 2001. Directive 2001/13/EC of 26 February 2001 amending Council Directive 95/18/EC on the licensing of railway undertakings, Official Journal of the European Union, L 75: 26-28.

European Commission. 2001. Directive 2001/14/EC of the European Parliament and of the Council. 2001. On the Allocation of Railway Infrastructure Capacity and the Levying of Charges for the Use of Railway Infrastructure and Safety Certification, Official Journal of the European Union, L 75: 29-46.

European Commission. 2007. Regulation (EC) No 1371/2007 of the European Parliament And Of The Council of 23 October 2007 on rail passengers' rights and obligations. 2007. Official Journal of the European Union, L 315: 14-41.

European Commission. 2007. Regulation (EC) No 1370/2007 of the European Parliament And Of The Council of 23 October 2007 on public passenger transport services by rail and by road and repealing Council Regulations (EEC) Nos 1191/69 and 1107/70. Official Journal of the European Union, L 315: 1-13. 
Dulanović, Ž.; Jaško, O. 2009. Organizaciona struktura $i$ promene, Fakultet organizacionih nauka, Beograd [Organizational structure and changes, Faculty of Organizational Sciences, Belgrade]. 441 p.

European Railway Policy. 2007. Project: First Alignment with the transport Acquis, Federal Ministry of Transport, Construction and Urban Affairs, Germany, Wolfgang Kupper. 7 p.

Feraboli, O. 2006. A Dynamic General Equilibrium Analysis of Jordan's Trade Liberalisation ( $\mathrm{PhD}$ dissertation). Chemnitz University of Technology, Faculty of Economics and Business Administration. Germany. $109 \mathrm{p}$.

IBM Business Consulting Services. 2007. Summary of the Study Rail Liberalization Index 2007, Market Opening. Rail Markets of the Member States of the European Union, Switzerland and Norway in comparison. Brussels, Belgium. $32 \mathrm{p}$.

International Union of Railways (UIC). 2008. Suggestion on Law for establishing the Agency for railway transport, Skopje, Macedonia. $56 \mathrm{p}$.

Law on Railways. 2005. Official Gazette of the Republic of Serbia. No. 18/2005. [In Serbian: Zakon o železnici. Službeni Glasnik RS 18/2005]. 35 p.

Milutinović, S. 2004. Local Agenda 21: The introduction in sustainable development planning. Standing Conference of Towns and Municipalities. [In Serbian: Lokalna Agenda 21: Uvod u planiranje održivog razvoja, Stalna konferencija gradova i opština]. Belgrade, Serbia. 179 p.

South East Europe Transport Observatory (SEETO). 2009. Exchange Of Information On Regional Legal Framework For Access To Railway Network And Draft Regulatory Manual, First Railway Reform Workshop For Task: Access To Railway Network. Belgrade, Serbia. 30 p.
Stojić, G. 2010. Model Development for Evaluation the Management of Railway Infrastructure ( $\mathrm{PhD}$ dissertation). Faculty of Technical Sciences, University of Novi Sad, Serbia. 173 p.

Stojić, G.; Tanackov, I.; Vesković, S.; Milinković, S. 2009. Modeling Evaluation of Railway Reform Level Using Fuzzy Logic. In Proceedings of the 10th International Conference on Intelligent Data Engineering and Automated Learning, Ideal '09. Burgos, Spain. DOI: http://dx.doi.org/10.1007/9783-642-04394-9_85. Springer-Verlag Berlin, Germany, 5788: 695-702.

The Community of European Railway and Infrastructure Companies (CER). 2005. Reforming Europe's Railways - An assesment of progress. Brussels, Belgium. 14 p.

White Paper. 2001. European Transport Policy for 2010: Time to Decide. European Commission. 119 p.

Zadeh, L.A. 1965. Fuzzy sets, Information and Control, DOI: http://dx.doi.org/10.1016/S0019-9958(65)90241-X, $8(3): 338-353$. 


\title{
MODEL ZA PROCENU LIBERALIZACIJE ŽELEZNIČKOG PUTNIČKOG SAOBRAĆAJA: PRIMER SRBIJE
}

\author{
Slavko Vesković, Vera Raičević, Gordan Stojić, \\ Sanjin Milinković
}

Sažetak: Tržišno učešće železničkog putničkog saobraćaja drastično je smanjeno u poslednjih pedeset godina. Zadatak reformi je otvaranje tržišta železničkih usluga i razvoj konkurencije u železničkom sektoru u cilju dobijanja koristi od "tržišnih snaga" i smanjenje intervencija u železničkom sektoru. Određivanje nivoa reformi često izaziva konfuziju i suprotstavljena mišljenja. To podrazumeva primenu intuicije i subjektivnih procena i ne koriste se direktne metode istraživanja, već kao rezime načina razmišljanja o trenutnoj poziciji. Ovo sugeriše da je prikladno da se koristi teorija fuzzy logike da se proceni nivo železničkih reformi. Fuzzy model izračunava nivo liberalizacije železničkih reformi kao izlaznu promenljivu, gde su inputi definisani kao: dinamika izvršenja, broj reformskih koraka, implementacije saobraćajne politike, itd. Procene nivoa liberalizacije železničkog tržišta i železničkih reformi je važan proces koji pokazuje u kojoj fazi se zemlje nalaze. Sinhronizacija nivoa reformi veoma je važna za zemlje u regionu zbog uspostavljanja stabilnog transportnog tržišta.

Ključne reči: železnica, prevoz putnika, liberalizacija tržišta, obaveza javnog prevoza, eksterni troškovi saobraćaja, fuzzy model. 